\title{
Isolated seafloor pockmarks linked to BSRs, fluid chimneys, polygonal faults and stacked Oligocene-Miocene turbiditic palaeochannels in the Lower Congo Basin
}

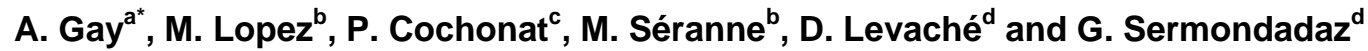 \\ ${ }^{a}$ National Oceanography Centre of Southampton (NOCS), Challenger Division for Seafloor Processes, Empress \\ Dock, CHD, Room 786/12, SO14 3ZH, Southampton, UK \\ buniversité de Montpellier 2, Laboratoire Dynamique de la Lithosphère, Montpellier, France \\ 'IFREMER, Département Géosciences Marines, Laboratoire Environnements Sédimentaires, Brest, France \\ ${ }^{\mathrm{d}}$ TOTAL, Pau, France \\ *: Corresponding author : National Oceanography Centre of Southampton (NOCS), Challenger Division for \\ Seafloor Processes, Empress Dock, CHD, Room 786/12, SO14 3ZH, Southampton, UK. Tel.: +44 2380686614. \\ ayg@noc.soton.ac.uk
}

\begin{abstract}
Based on high-resolution 3D seismic data sets, we document the subsurface reservoir architecture and organization of a portion of the Oligocene-Miocene stratigraphy within the Congo Basin, offshore southwestern Africa. Within the 3D seismic volume, we have identified four levels of turbiditic palaeochannels, which are separated by low-amplitude continuous reflectors interpreted as hemipelagic sediments. Geochemical analyses on sediment samples taken within overlying seafloor pockmarks reveal the presence of thermogenic gases and oils, suggesting that deep-seated fluids have migrated through both the channel deposits and the impermeable layers between them, forming a conduit to the surface. Deep thermogenic fluids produced within Cretaceous source rocks are preferentially entrapped within coarse-grained turbiditic Oligocene-Miocene palaeochannels. We show in this study that the vertical stacking pattern of turbiditic palaeochannels allows the best pathway for fluids migration. Once the fluids migrate to the upper layer (i.e., Upper Miocene) of palaeochannels, they can reach the seafloor via migration along a highly faulted interval composed of polygonal faults. They are temporarily inhibited below an interpreted 300-m-thick gas hydrate layer marked by a strong BSR on seismic profiles. Fluids accumulate under the hydrate stability zone to form a thick layer of free gas. The generation of excess pore fluid pressure in the free gas accumulation leads to the release of fluids along faults of the highly faulted interval forming pockmarks on the seafloor. Ultimately, we show in this study that fluids are progressively concentrated in the sedimentary column and aligned pockmarks on the seafloor may represent a focused fluid flow from stacked turbiditic palaeochannels.
\end{abstract}

Keywords: fluid migration; pockmarks; turbiditic palaeochannels; hydrates; pipes; fluid chimneys; BSR; polygonal faults 


\section{Introduction}

Evidences of offshore fluid seeps at the seabed were first reported on sidescan records from the Scotian Shelf by King and MacLean (1970). Fluid seeps generally appear in unconsolidated fine-grained sediments as cone-shaped circular or elliptical depressions named pockmarks. They range from a few meters to $300 \mathrm{~m}$ or more in diameter and from $1 \mathrm{~m}$ to $80 \mathrm{~m}$ in depth. Pockmarks generally concentrate in fields extending over several square kilometers where they often appear as isolated patches named single pockmarks or "eyed pockmarks" (Hovland and Judd, 1988). In some cases, they have been identified along straight or circular lines correlated with glaciomarine tills (Josenhans et al., 1978; Whiticar and Werner, 1981; Kelley et al., 1994; Ussler III et al., 2003) or suggesting a structural control on fluid flow (Eichhubl et al., 2000; Paull et al., 2002; Loncke et al., 2004). In particular, structural surfaces along bedrock (Shaw et al., 1997), salt diapirs (Schmuck et al., 1993; Taylor et al., 2000) and faults and faulted anticlines (Boe et al., 1998; Soter, 1999; Vogt et al., 1999; Eichhubl et al., 2000; Dimitrov et al., 2003) create pathways for fluid migration. Pockmarks are known to occur on continental slopes with gas hydrates (Bünz et al., 2003; Johnson et al., 2003; Zühlsdorff et al., 2004) and in association with slides and slumps (Hovland et al., 2002; Lastras et al., 2004). These observations suggest that discontinuities and/or unconformities are more effective fluid conduits than homogeneous sections of stratigraphy that are dominated by intergranular fluid flow (Abrams, 1992; Brown, 2000) and are thus more likely the conduits responsible for pockmark development (Abrams, 1996; Orange et al., 1999). These observations suggest that the nature of fluids expelled and the organization of pockmarks on seafloor may be indicative of the depth of the reservoir and of the potential fluid migration pathways (Heggland, 1998).

Understanding fluid flow processes through sediments need first to improve our knowledge of large-scale fluid pathways and of fluid migration processes within a sedimentary basin. Our study area, located within the Lower Congo Basin (LCB), is characterized on the seafloor by groups or isolated small circular pockmarks, ranging from $100 \mathrm{~m}$ to $300 \mathrm{~m}$ in diameter, and from a few meters to a maximum of $20 \mathrm{~m}$ in depth (Gay et al., 2003). They seem mostly unevenly distributed and their abundance varies considerably across the area. Pockmarks develop, in particular, in areas covered by 1 to $3 \mathrm{~km}$-regularly spaced linear depressions. These furrows are interpreted as the seafloor expression of small-scale polygonal faults that cut through an underlying interval, $600 \mathrm{~m}$ thick, serving as shallow subsurface fluid conduits to the seafloor (Gay et al., 2004).

Seismic profiles issued from high-resolution 3D seismic datasets show that these apparent isolated pockmarks are clearly related to deep buried turbiditic palaeochannels, which may have concentrated thermogenic fluids before upward redistribution. Geochemical analyses conducted on cores within some of these pockmarks show clear evidence of deep thermogenic fluids (Gay et al., Submitted). In this paper we show that the nature of expelled fluids and the location of isolated pockmarks are clearly controlled by 1 ) the stacking pattern of four OligoceneMiocene turbiditic palaeochannels, 2) the presence of an impermeable gas hydrate layer, which may temporarily inhibit the fluid migration and 3) the development of an Highly Faulted Interval (HFI) hosting polygonal faults that allow fluid migration to reach the seafloor. In frontier exploration, knowledge of reservoirs architecture and organization will constrain risk assessment, help the development of appropriate drilling strategies and improve the prediction of fluid migration pathways and seepages locations. 


\section{Data base and processing}

This study is primarily based on 3D exploration seismic datasets from the Lower Congo Basin (LCB) acquired by TOTAL (Fig. 1). The selected 3D-dataset covers about 2400 square kilometers with a line spacing of $12,5 \mathrm{~m}$ and a CDP distance of $12,5 \mathrm{~m}$ (Fig. 2). They were loaded to a workstation and interpreted with the SISMAGE software developed by Total-Fina-Elf. 3D seismic imagery allows extraction of continuous horizons within the 3D block and calculation of seismic attributes (Brown, 1996). The automatic picking on conventional seismic profiles (i.e. seismic attribute) is suited to the interpretation of continuous horizons. Irregular sedimentary bodies or post-depositional structures, such as faults, fluid chimneys and turbiditic palaeochannels, cannot be delineated by conventional horizon picking and require the calculation of new seismic attributes.

Figure 1: Bathymetric map of the Lower Congo Basin issued from the EM12 multibeam acquisition (ZAIANGO project, 1998-2000). This map shows the Zaire system from the Zaire estuary to the basin at $4000 \mathrm{~m}$ water depth. The 3D seismic dataset used in this study (shaded rectangle) is located on the slope, between 950 and $1850 \mathrm{~m}$ water depth, north of the Zaire canyon. The three sites of the ODP Leg 175 in this zone are indicated.

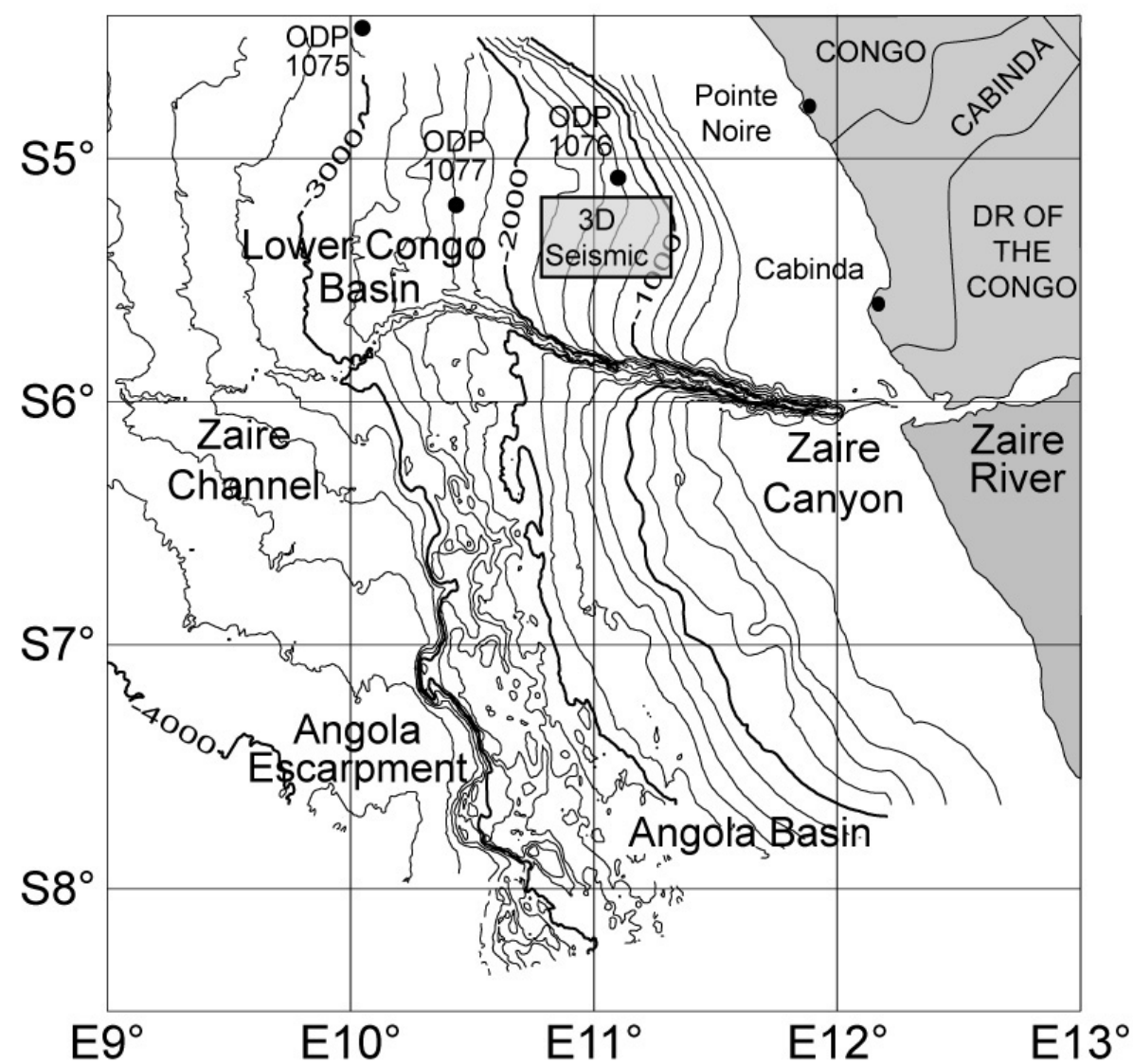


Figure 2: Dip map of seafloor in the Lower Congo Basin, calculated from the 3D data. A dip map is the derived surface of a isochron map that illuminates, from white to black, horizontal to inclined surfaces respectively. This map illustrates the seafloor facies characterized by pockmarks and furrows. The white lines represent seismic profiles issued from the 3D seismic dataset used in this study. The bathymetry issued from the EM12 multibeam acquisition is reported. Geochemical analyses conducted on cores $\mathrm{Ca}, \mathrm{Cb}, \mathrm{Cc}$ and $\mathrm{Cd}$ within four pockmarks show evidence of thermogenic hydrocarbons.
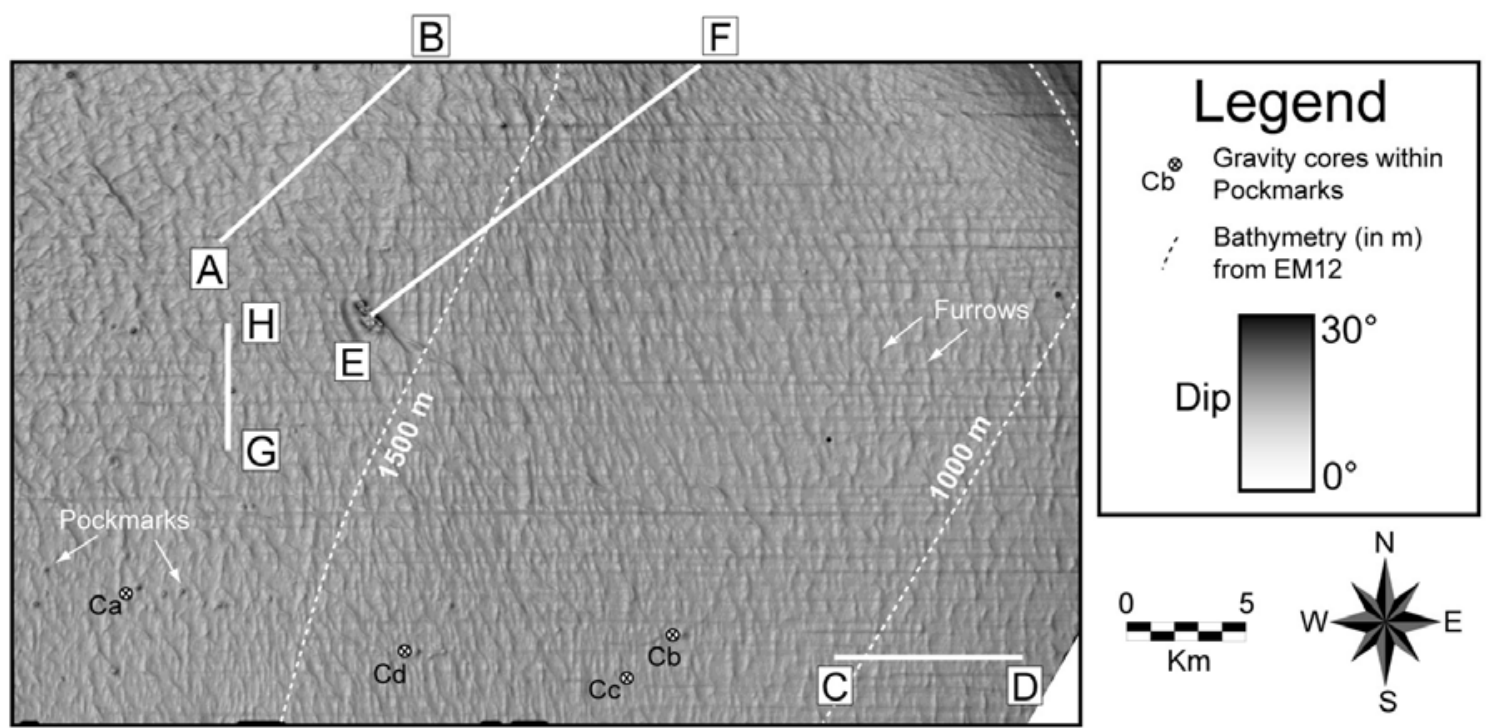

\section{The "Chaotism" attribute}

Due to the discontinuous character of turbiditic palaeochannel infills, an automatic picking of sand bodies is difficult. New tools in the academic and petroleum exploration domains allow to individualize these chimneys from the 3D block. Based on the amplitude of reflectors and their continuity, however, the SISMAGE software developed by TOTAL does allow the calculation of the "Chaotism" amplitude attribute from a 3D seismic survey. In the derived 3D-chaotism block, turbiditic palaeochannels appear as homogeneous high-amplitude anomalies, ovoid in shape, 1 to $4 \mathrm{~km}$ wide (Fig. 3). We have then considered the average value of "Chaotism" within each interval previously identified on seismic that allows to determine four different levels of turbiditic palaeochannels. 
Figure 3: Seismic profile $A B$ showing discontinuous high amplitude reflectors interpreted as turbiditic palaeochannels within the Oligocene-Miocene Interval. 3D seismic allows to calculate other attributes such as "Chaotism". The turbiditic palaeochannels, now well individualized with this attribute, are easily mappable by automatic picking.

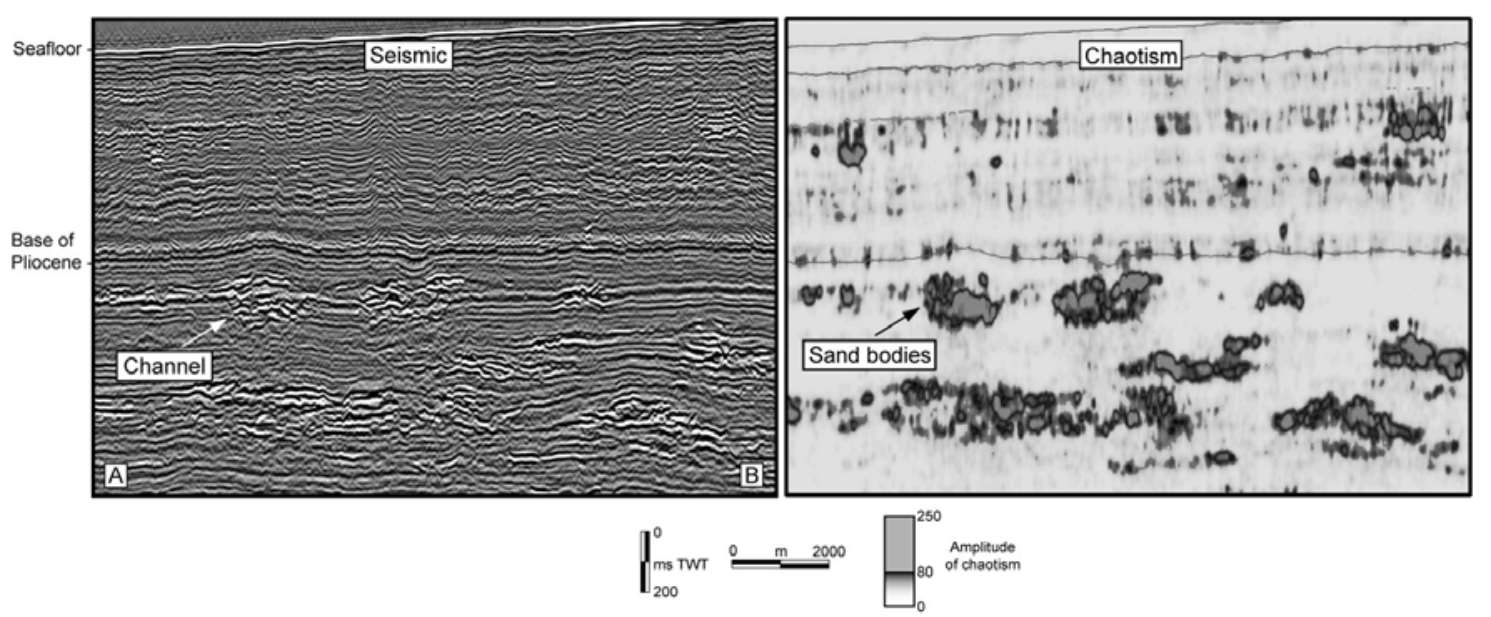

\section{The "Fault" attribute}

Fluid chimneys are commonly characterized by two superposed acoustic anomalies (Fig. 4). They may represent present migration of fluids in the sedimentary column (Heggland, 1998; Hempel et al., 1994; Tingdahl et al., 2001). The shallowest anomaly is vertically elongated and ovoid in shape, 50-250 msTWT high and 50-150 $\mathrm{m}$ wide. On seismic profiles, these anomalies are underlined by depressed highamplitude reflectors interpreted as a reduction of the seismic velocities (pull-down effects) through a gas charged column. Similarly to the "Chaotism" attribute, the SISMAGE software allows to calculate the "Fault" amplitude of a 3D seismic block. It is based on vertical discontinuities of reflectors and the fluid chimneys appear as homogeneous vertically elongated columns easily mappable by automatic processes. The seismic profile $C D$ shows that they may connect down to turbiditic palaeochannels and may act as a preferential drain for deep fluid migrations (Fig. 4).

Figure 4: Seismic profile CD showing seismic chimneys of migrating fluids. These chimneys are characterized by a shallow part, with high amplitude depressed reflectors interpreted as a gas charged chimneys, and a deep part that corresponds to a fade-out of the reflectors in an inverted cone shape interpreted as an acoustic turbidity. As described for palaeochannels, these objects are very difficult to extract from the 3D block. Here the "Fault" attribute is used and allows to individualize vertical discontinuities such as seismic chimneys.

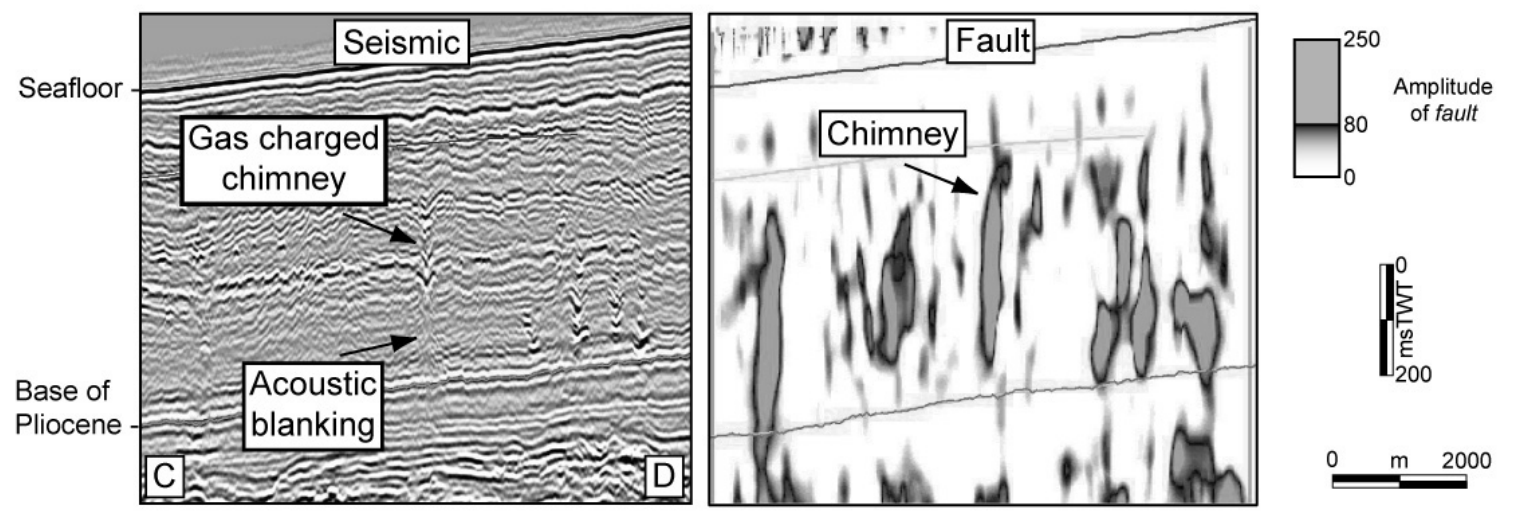


A.Gay et al - Pockmarks related to stacked turbiditic palaeochannels

\section{Geologic setting}

The 3D seismic dataset is located on the slope (950 to $1850 \mathrm{~m}$ water depth) of the Lower Congo Basin (LCB). The LCB is one of the numerous sub-basins of the West African passive margin developing during the opening of the South Atlantic Ocean at early Cretaceous (Jansen et al., 1984a; Marton et al., 2000). Subsequent to large accumulations of evaporites (up to 1000m) during the mid-Aptian time (Karner et al., 1997), the post-rift stratigraphy is characterized by two superposed seismic architectures that reflect a major change in ocean circulation and climate (Seranne et al., 1992).

From Late Cretaceous to early Oligocene time, an aggradational carbonate/siliciclastic ramp developed in response to low-amplitude/low-frequency sea-level changes and a stable climate (greenhouse period) (Seranne, 1999). This interval is characterized by Tertiary source rocks that produce thermogenic oils and gases through cracking of organic matter (Burwood, 1999) (Fig. 5). 
Figure 5: Seismic profile EF. The post-rift stratigraphy is characterized by two superposed seismic architecture: 1) an Albian to Eocene sequence containing the source rocks and 2) an Oligocene to Present sequence containing the reservoirs (turbiditic palaeochannels) and the sedimentary cover (affected by an Highly-Faulted Interval). Deep thermogenic fluids migrating from the source rock are preferentially entrapped into the coarse grained (sand/silt infills) palaeochannels, playing the role of reservoirs.
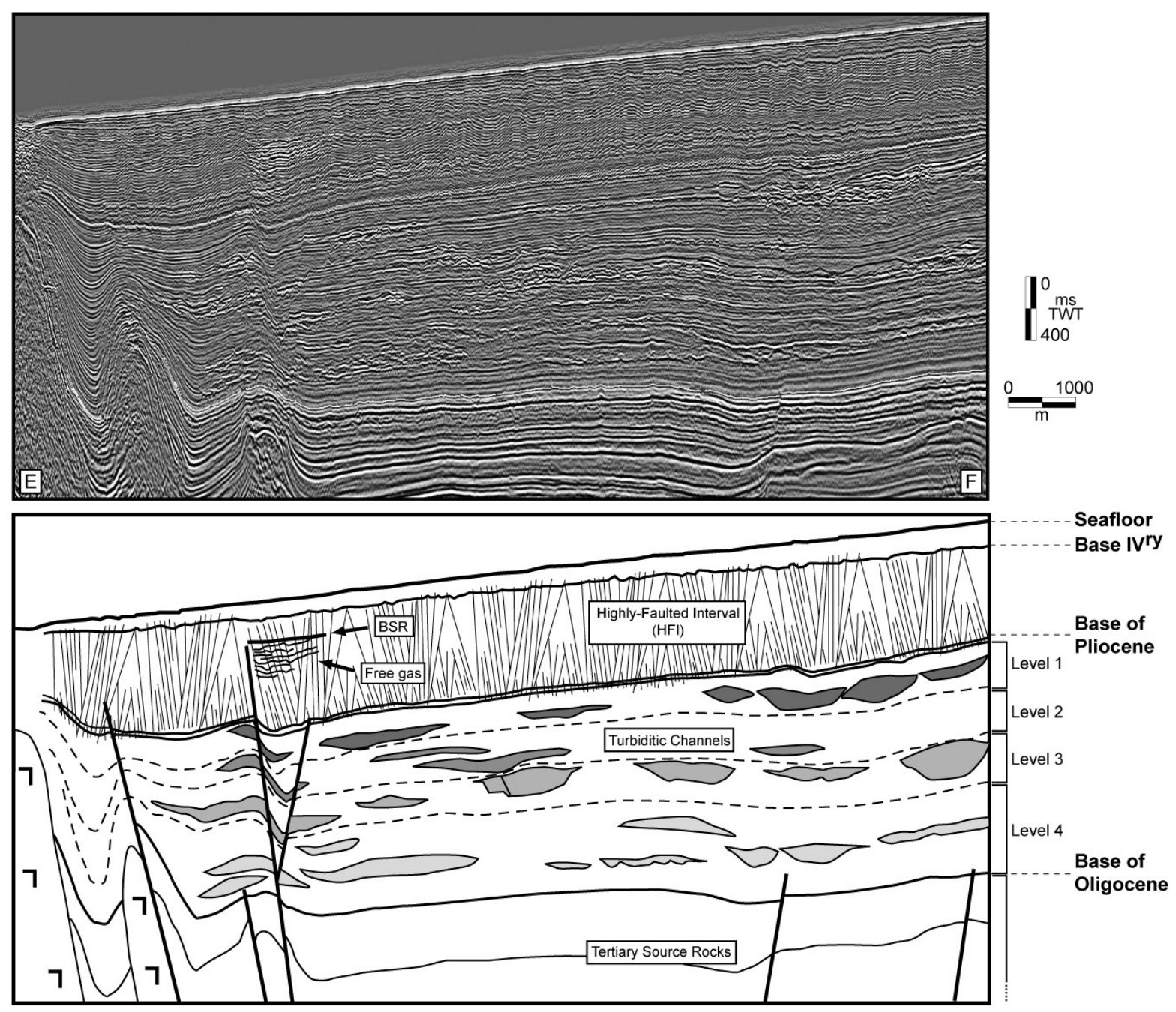

From early Oligocene to Present time, the sedimentation was dominated by the progradation of a terrigenous wedge that reflect high-amplitude/high-frequency sea-level changes and an alternating drier and wetter climate. These high-frequency alternating climatic conditions have caused deep incision and erosion. The large amounts of terrigenous material has led to the formation of the Zaire system, a large turbiditic submarine fan characterized by numerous turbiditic palaeochannels (Brice et al., 1982; Droz et al., 1996; Uchupi, 1992). A portion of this fan system is preserved in the Oligocene-Miocene interval imaged in the 3D seismic volume discussed here. Updip migration of deeper thermogenic fluids (Gay et al., submitted)are preferentially trapped in these coarse grained (likely silty-sandy) palaeochannels, which now serve as hydrocarbon reservoirs (Burwood, 1999).

Further south, in the Angola Basin (Block 4), turbidite sands are commonly associated with three major turbidite bearing depositional sequences (Anderson et 
al., 2000): the 17.5-15.5 Ma sequence (Burdigalian, early Miocene), the 8.2-6.3 Ma sequence (Tortonian, Late Miocene), and the 6.3-5.5 Ma sequence (Messinian, Late Miocene). Based on geological interpretations of 3D seismic profiles in the study area described here, we identify four levels of distinct turbiditic palaeochannels within the Oligocene-Miocene interval (Fig. 5):

- Level 1: Base Pliocene / Base Pliocene + 260 ms TWT

- Level 2: Base Pliocene + 260 ms TWT / Base Pliocene + 430 ms TWT

- Level 3: Base Pliocene + 430 ms TWT / Base Pliocene + 640 ms TWT

- Level 4: Base Pliocene + 640 ms TWT / Base Oligocene

From early Pliocene time to Present, the shelf and the slope are deeply incised by a canyon that directly connects the Congo River with the basin floor at the toe of the continental slope, down to $4000 \mathrm{~m}$ water depth (Babonneau et al., 2002). During the ODP Leg 175, three sites were drilled at varying positions from the shelf break (sites 1075, 1076 and 1077) within the LCB. The lithostratigraphy of Late Neogene sediments suggests that turbidity currents played a minimal role in transporting sediment within the LCB (Giraudeau et al., 1998); (Pufahl and Wefer, 2001). Presumably, the sediments trapped into the canyon were carried far onto the lower fan, starving the shelf of coarse detritus (Jansen et al., 1984b); (UenzelmannNeben, 1998); (Savoye et al., 2000). Only fine muddy sediments not confined to the canyon are delivered to the LCB, perhaps from riverine plumes, through sedimentation by aggregates and in fecal pellets (Wefer et al., 1998); (Cooper, 1999) and mixed with hemipelagic sediments on the continental shelf and slope. The Pliocene-Present interval plays the role of a seal cover above the Oligocene-Miocene turbiditic interval (Burwood, 1999) (Fig. 5).

One of the main tectonic features of the West African margin is the gravitational sliding of post-rift sediments above a décollement layer made up of Aptian evaporites (Duval et al., 1992); (Lundin, 1992); (Liro and Cohen, 1995). In the Lower Congo Basin, gravitational processes created two structural domains each about $100 \mathrm{~km}$ wide: an extensional domain on the upper slope and a compressive domain located downslope that are partly active today. The extensional domain is locally associated with large amounts of extension across listric faults creating individual rafts and grabens (Burollet, 1975); (Duval et al., 1992); (Rouby et al., 2002).

\section{Results}

\section{Seismic expression of fluid migration}

In the southern part of the study area, the seismic profile $\mathrm{GH}$ crosses a single pockmark and its underlying chimney, which is characterized by downward deflected high-amplitude reflectors (Fig. 6). The chimney is disrupted by a highamplitude reflection parallel to the seafloor located 200-300 ms TWT below the seafloor. This reflection is interpreted as a Bottom Simulating Reflector (BSR), which corresponds to the lower thermodynamic limit of the gas-hydrate stability zone (Shipley et al., 1979; Kvenvolden and Barnard, 1983; Hyndman et al., 1992) or to the top of the free gas zone beneath the hydrates (MacKay et al., 1994). BSR's are characterized by a reverse polarity compared to the seafloor reflection, indicating a decrease in seismic impedance and therefore of seismic velocity. This contrast in impedance is probably due to the presence of free gas entrapped below the gas hydrate stability zone, and the BSR can be considered as the interface between highvelocity gas hydrates and the underlying gas-charged sediments with low seismic 
velocities (Mackay et al., 1994). The seismic profile $\mathrm{GH}$ shows that the BSR is deflected upward directly beneath the seismic chimney and the seafloor pockmark. This upward deflection of the BSR suggests a localized positive heat flow anomaly, which could be due to an ascending movement of fluids through the sedimentary column (De Batist et al., 2002).

Figure 6: Seismic profile GH across a single pockmark. The chimney under the pockmark is disrupted by a high-amplitude reflection parallel to the seafloor, which is interpreted as a BSR. This seismic profile shows that the BSR is deflected upward, suggesting a localized positive heat flow anomaly and an ascending movement of fluids. The Pliocene to present interval is affected by a Highly-Faulted Interval (HFI). We consider that this interval can act as a major process for driving up fluids entrapped within underlying Oligocene-Miocene turbiditic palaeochannels.

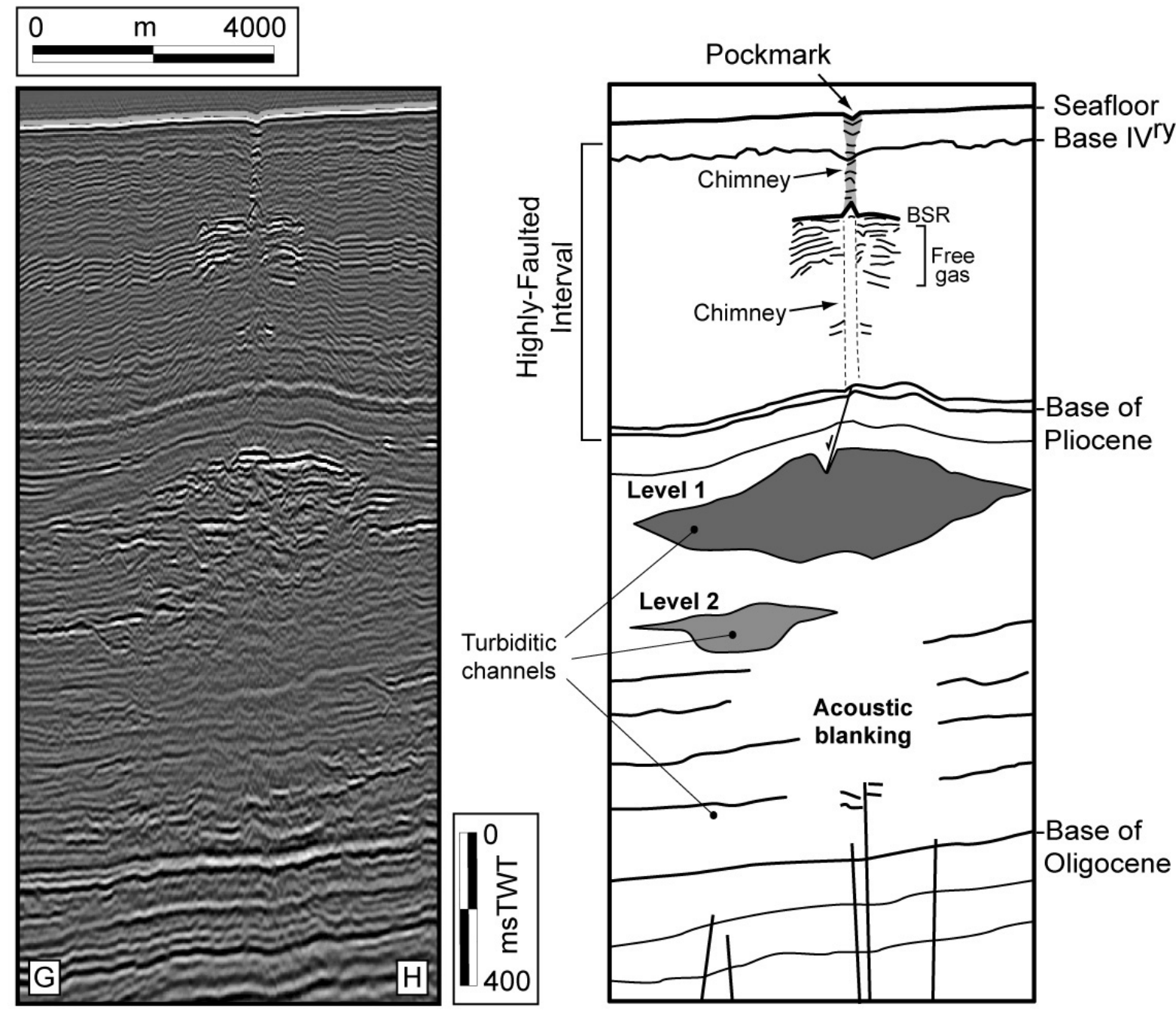

All seismic profiles within the study area show a Highly-Faulted Interval (HFI) in the first 0-800 msTWT below seafloor (Fig. 6). The HFI (described in detail in Gay et al., 2004) is characterized by numerous closely spaced normal faults, which have small offsets $(5-30 \mathrm{~m})$ and an average spacing $(100-500 \mathrm{~m})$. These faults draw large polygons in plan view, ranging from $1 \mathrm{~km}$ to $3 \mathrm{~km}$. Since the first recognition of a polygonal fault system in the Leper Clay of Belgium (Henriet et al., 1991), numerous examples of layer-bound polygonal fault systems have been described worldwide from 3D seismic data (Klitgord and Grow, 1980; Poag et al., 1987; 
Cartwright, 1994; Oldham and Gibbins, 1995; Cartwright and Lonergan, 1997; Cartwright and Dewhurst, 1998; Lonergan et al., 1998a; Lonergan et al., 1998b). Due to the fine grained lithology of Pliocene-recent sediments and the map view polygonal network of faults, we suspect the HFI results from layer-parallel volumetric contraction of fine-grained sediments leading to the pore fluids escape (Cartwright and Lonergan, 1996). Although sand bodies located above rift-related basin-forming faults appear especially susceptible to act as major vertical fluid escape pathways (Lonergan et al., 2000), we consider that the Highly-Faulted Interval may compromise the seal capacity of the Pliocene sedimentary cover. The polygonal faults may act as a major process for driving up fluids entrapped within underlying Oligocene-Miocene turbiditic palaeochannels (Gay et al., Submitted).

The Oligocene-Miocene turbiditic palaeochannels appear on the seismic as high-amplitude packages with strongly scoured/erosional bases indicating deposition in a largely channelized environment (Fig. 6). To the south, where these palaeochannels have been cored (Anderson et al., 2000), massive sands often form the basal units of sequences that grade upwards into a succession of horizontally laminated fine sands and silts, overlain by wavy, lenticular bedded silts and interbedded muds. Anderson (2000) has shown that dewatering structures are common and in some cases may have resulted in total homogenization of the sands. An alternative model for the lack of clearly defined sedimentary structures in the sands and grading within these beds is rapid deposition from suspension in a highdensity turbidite flow (Lowe, 1982). The fining upwards sequences consisting of more thinly bedded fine sands and silts are interpreted as classic fine to medium grained, low to medium density turbidite deposits (Bouma sequences: Bouma, 1962).

The difficulty in interpretation strongly increases where reservoirs comprise stacked turbidite systems and such stacked reservoirs systems are relatively common phenomena (Richard and Bowman, 1998). Here, predictions of reservoir architecture based upon a single model will fail to appreciate the spatial changes in reservoir geometry and shale architecture. We resolved this problem by using a new tool based on the "Chaotism" of a seismic profile, developed by TOTAL for the Sismage software.

\section{Organization of turbiditic palaeochannels}

Based on the identification of four levels of turbiditic palaeochannels on seismic profiles, we transformed the seismic block into a "Chaotism" block that allows to map these palaeochannels (See Database and Processing section for more details). The map view expression of the turbiditic palaeochannels (i.e. average value of "Chaotism" within the four intervals) exhibit a variety of forms including high sinuosity channels with well-developed levee systems or relatively straight channel segments (Fig. 7). Depositional processes are believed to be responsible for the dominantly linear shape and channelized cross-sectional geometry of most deep water turbidite fan channel reservoirs. The maps of the average value of "Chaotism" within the four levels show that the overall trend of the palaeochannel complexes is ESE/WNW cutting obliquely across the major faults (i.e. normal and reverse faults due to the gravitationnal sliding of the post-rift sequence). In the northeastern corner of the study area the palaeochannels are deflected to the south near the normal faults bordering an extensional graben, implying the faulting was prior or occurred during the channel development. In the centre of the study area some palaeochannels are deflected near underlying salt diapirs suggesting that they developed during active salt diapirism. We also notice that the current fan channel reservoir geometry is influenced by the location of extensional or compressive postrift faults. The dominant orientation of turbidite palaeochannels corresponds to the 
direction of the sediment supply issued from the Zaire River mouth and is related to the progradation of the Zaire fan pro-delta across the study area.

Figure 7: "Chaotism" maps of turbiditic palaeochannels. Based on the identification on seismic profiles of four levels of turbiditic palaeochannels (levels 1 to 3 are Miocene and the level 4 is Oligocene), we transformed the seismic block into a "Chaotism" block using the Sismage software. The average value of "Chaotism" within each interval is then calculated and projected on a map view. These maps exhibit a variety of forms including high sinuosity channels with well-developed levee systems or relatively straight channel segments. The overall trend of the palaeochannel complexes is ESE/WNW.

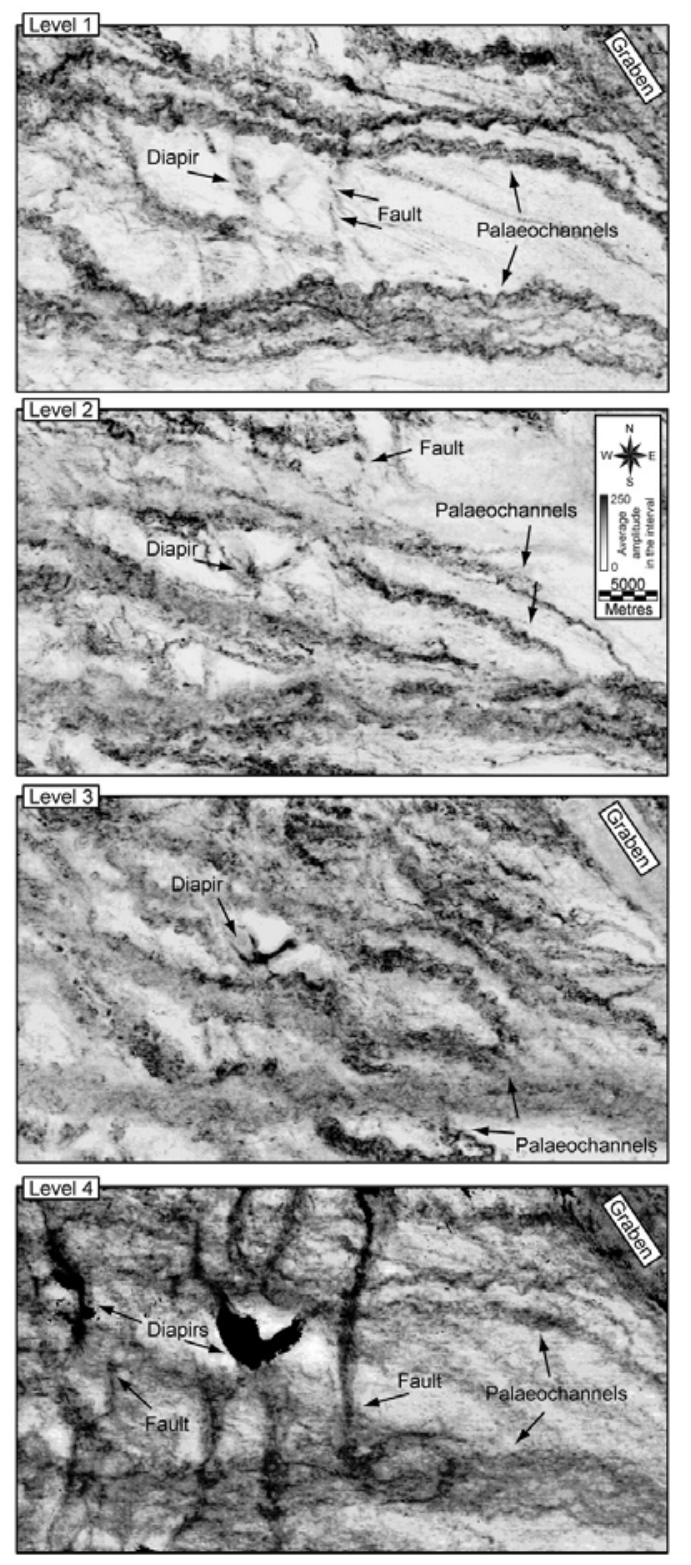

Relation between stacked palaeochannels and seismic chimneys under the $\underline{B S R}$

The use of the "Fault" attribute allows to extract fluid chimneys from the seismic block (See "Database and processing" section fore more details). These chimneys can be projected in any 3D view as the basinward perspective view (i.e. toward the West) shown in Figure 8. In this figure the level 1 of upper-Miocene 
turbiditic palaeochannels is projected on the Base Pliocene and fluid chimneys from the Pliocene interval are represented. The Base Pliocene is intensively deformed by structural features such as normal and reverse faults and large domes, 5 to $10 \mathrm{~km}$ wide. The domes correspond to the deformation induced by underlying salt diapirs. Some chimneys develop on the top of these domes and are attributed to a normal faulted network due to the collapse above the diapir crest (Stewart, 1999). Similar diapir chimneys offshore Nigeria have been discussed by Heggland (Heggland, 1997) and Graue (Graue, 2000).

Figure 8: Basinward perspective view within the 3D seismic block (toward the west). The level 1 of turbiditic palaeochannels is projected on the Base Pliocene (i.e. the top boundary of this level). The channel meander loops are highlighted in black while hemipelagic muds are in white. The seismic chimneys, extracted from the 3D seismic block using the "Fault" attribute, are represented. The base of the vertically elongated seismic chimneys seems to connect with meander loops of turbiditic palaeochannels. However, the apparent isolated chimneys may connect to deeper palaeochannels.

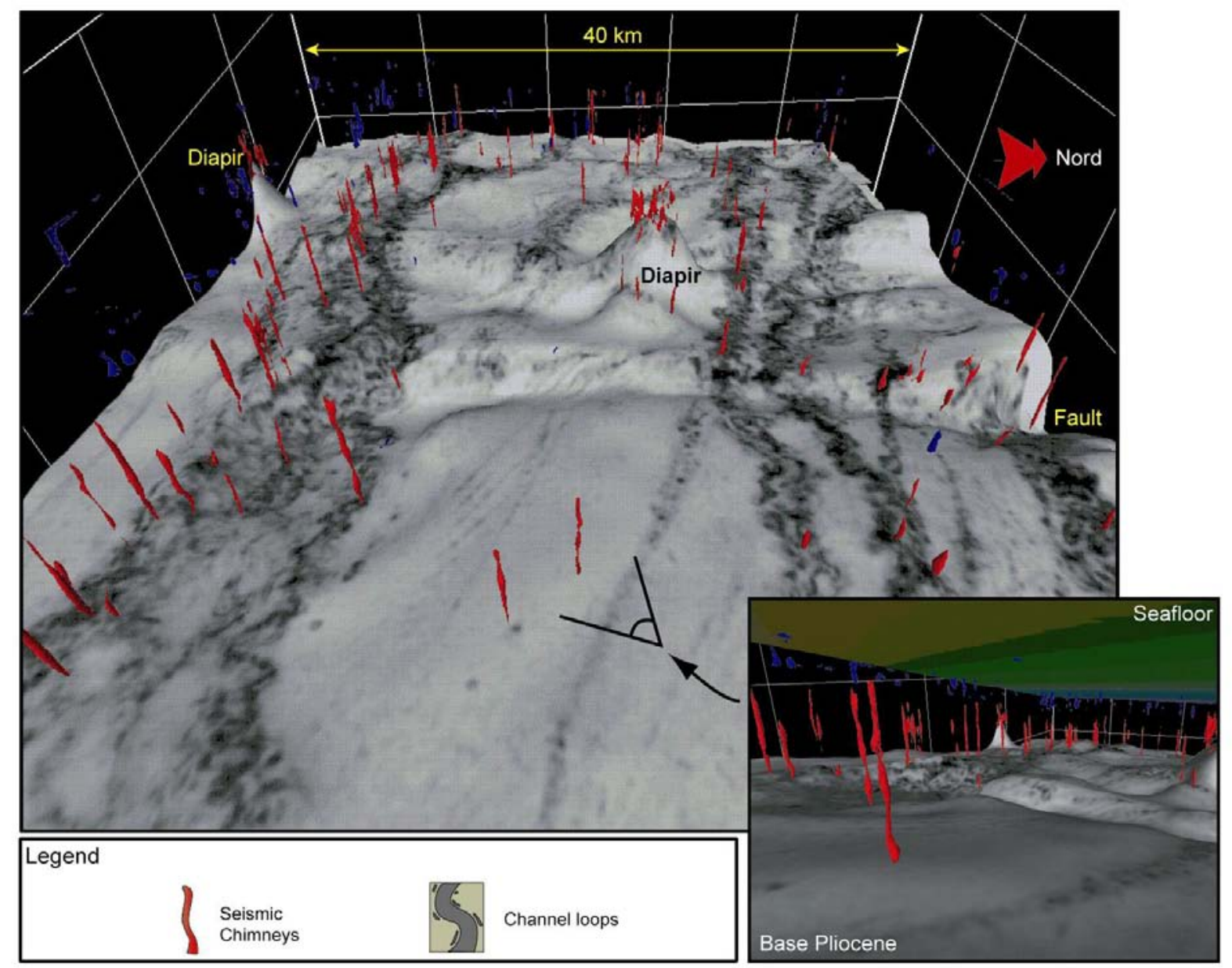

The base of the vertically elongated seismic chimneys seems to connect with meander loops of turbiditic palaeochannels. Even if this interval is projected on the base Pliocene, this statement has been verified through the 3D seismic block. However, numerous chimneys are not clearly connected to any palaeochannel of level 1. The apparent isolated chimneys, which are far from any major structure (i.e. faults, diapirs or turbiditic palaeochannels), may connect to deeper palaeochannels. 
In fact, all seismic chimneys take root over turbiditic palaeochannels but not always at the same level.

The map of vertically stacked palaeochannels of the four Oligo-Miocene levels shows large bands, 2 to $8 \mathrm{~km}$ wide (Fig. 9). The widest band is located in southern part of the study area. This band is oriented EW and corresponds to the strongest stacking pattern: in this zone, three to four levels of turbiditic palaeochannels are vertically stacked. In the northern part of the study area, the bands are mainly oriented SE-NW and do not exceed 2 to 3 stacked levels of palaeochannels. The seismic chimneys under the BSR are consistently located above the bands of highly stacked palaeochannels, suggesting that the fluids migrate through several levels of turbiditic palaeochannels.

Figure 9: Frequency map of vertical stacked palaeochannels. The triangles represents the position of seismic chimney under the BSR. This figure shows large bands, 2 to $8 \mathrm{~km}$ wide, of stacked palaeochannels. In the south of the study area, the bands are mainly oriented EW while they are oriented SE-NW in the north. The seismic chimneys under the BSR are consistently located above the bands of highly stacked palaeochannels, suggesting that the fluids migrate through several levels of turbiditic palaeochannels.
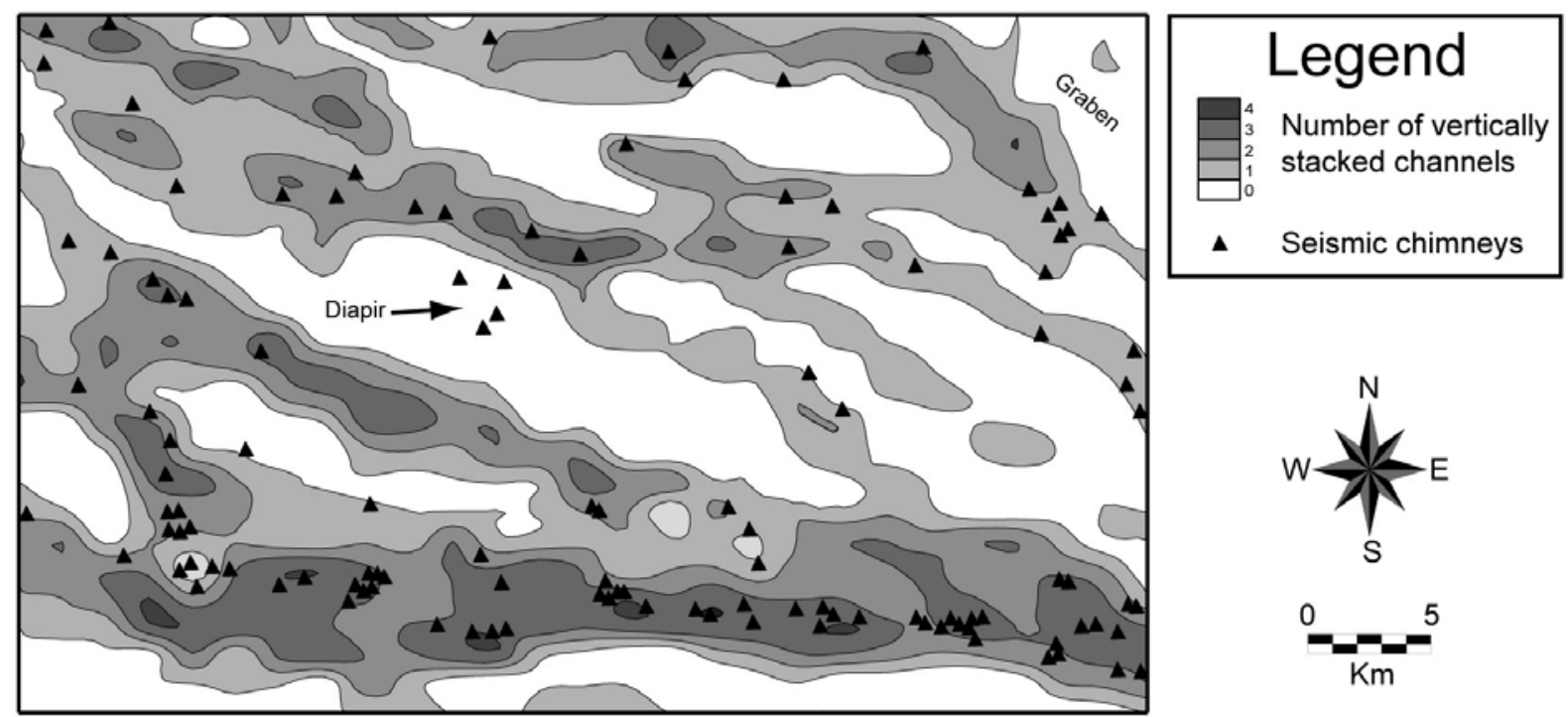

Relation between stacked turbidite palaeochannels, BSR, fluid chimneys and seafloor pockmarks

In the study area all the seismic profiles show that a BSR with underlying free gas zone occur over turbiditic palaeochannels, suggesting that gas hydrates may act as an impermeable layer, inhibiting fluid escape to the surface. The 3D seismic data allow us to map the area covered by a visible Bottom Simulating Reflector (BSR) on seismic (Fig. 10). In the study area, the BSR is defined by parallel bands, 2 to $5 \mathrm{~km}$ wide, dipping towards the WNW from 1800 msTWT in the East to a max of about 2800 msTWT in the West. An extensive mapping of the BSR in the Congo Basin has shown that the BSR extends from $800 \mathrm{~m}$ down to $3200 \mathrm{~m}$ water depths (Cunningham and Lindholm, 2000). As described in most basins worldwide, an active BSR parallels the seafloor. In the Lower Congo Basin the main slope of the BSR is parallel to the seafloor slope (see Fig. 1 and 2). Finally the BSR covers less than half of the study area. What prevails on the isochronal map of the BSR is the organization in bands 
oriented ESE-WNW, which are located exactly above areas of high stacking levels of turbidite palaeochannels. Furthermore, present day seafloor pockmarks have been reported on the map of the BSR. All pockmarks with their underlying chimneys are located above the BSR, except one near $2000 \mathrm{~m}$ water depth. It could be due to the progradation of slope that moves the BSR basinward as the sediments are deposited. This isolated pockmark is probably inactive at the present day.

Figure 10: Isochronal map of a Bottom Simulating Reflector (BSR) visible on 3D seismic sections in the study area. The BSR is dipping towards the WNW and parallels the seafloor slope. Present day seafloor pockmarks (white circles) with their underlying chimneys are located above the BSR and above areas of high stacking levels of turbidite palaeochannels. This indicates that the fluid pathways are directly linked to the organization of sedimentary bodies (i.e. palaeochannels) and/or to the structuration of the basin.
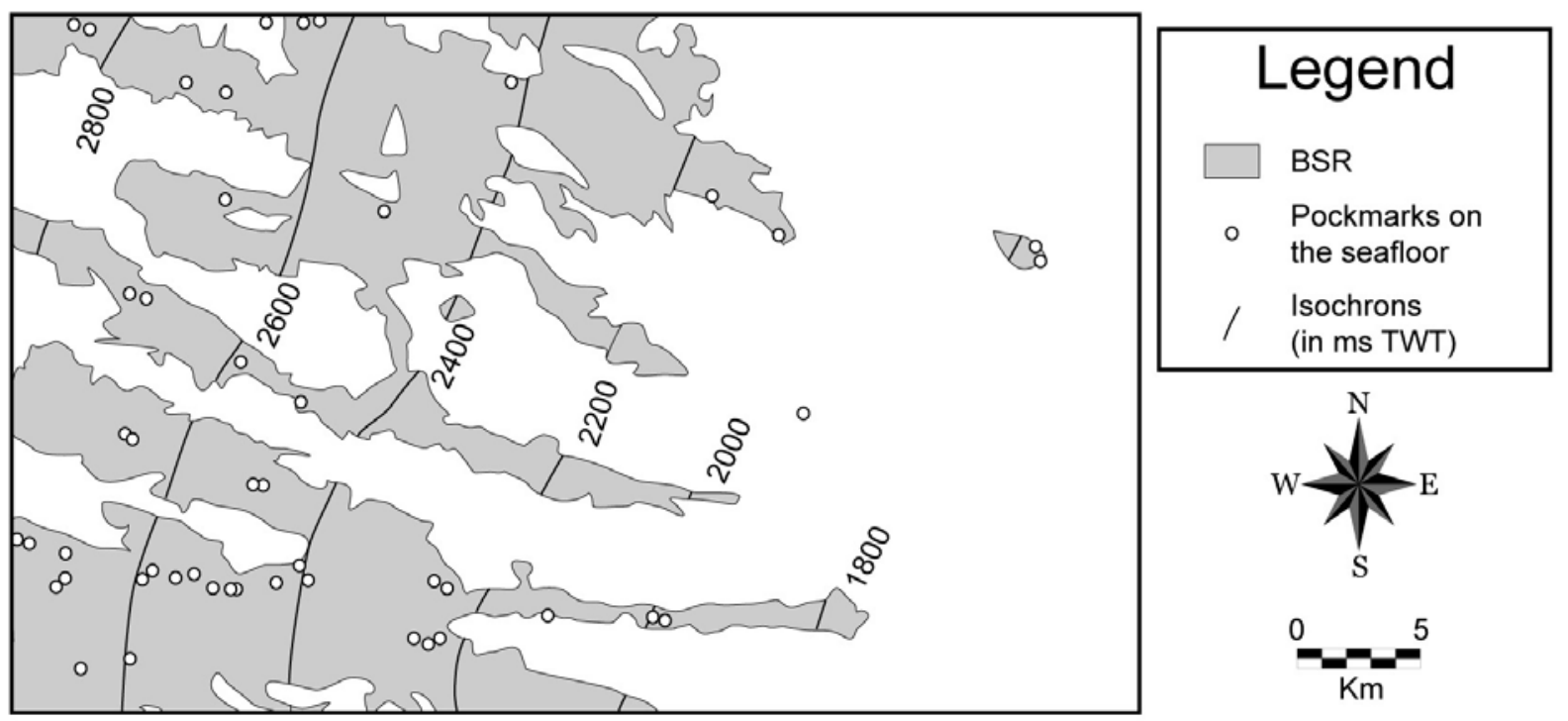

\section{Discussion}

\section{Vertical fluid migration through turbiditic palaeochannels}

Due to the high porosity of silts and sands, which we interpreted in our study area to compose the palaeochannel infills, the Oligo-Miocene palaeochannels may concentrate thermogenic fluids migrating from the productive underlying source rocks (Burwood, 1999). The palaeochannels are acting as effective longitudinal drains for the fluids to migrate (Tokunaga, 2000; Gay et al., 2003). As shown by Lonergan (2000) and Gay (submitted), injections and fluid escape occurred early within the burial history before significant compaction. Syn-depositional major faults located above turbiditic sand bodies may periodically act as main vertical fluid escape pathways (Lonergan et al., 2000). However, the main problem is the ability of fluids to migrate from a sand body to another and that depends on several parameters:

1) Vertical stacking of palaeochannels: The turbiditic palaeochannels have regionally persistent surfaces that separate sandstone-dominated lithologies from overlying shale-dominated lithologies. The seismic expression of this change is marked by low amplitude and moderately continuous seismic facies overlying high amplitude and variable continuity seismic facies. This transition is interpreted as an 
abandonment surface, which marks a geologically abrupt end of deepwater sand deposition (Jennette et al., 2003).

2) Lithology: the coarse nature of deposits (grainflows, debris-flows or high-density turbidity currents) determines the ability of fluids to migrate longitudinally through turbiditic palaeochannels (Gay et al., 2003).

3) Connectivity: Sand-rich intrusions, such as sill and dykes, may represent a preferential pathway for fluids to connect turbiditic palaeochannels (Lonergan et al., 2000).

4) Overpressure: Overpressure development in sedimentary basins is directly related to lithology, sedimentation rate, thermal expansion of fluids, transformation of clay minerals and hydrocarbon generation or bacterial methanogenesis ( $\mathrm{Yu}$ and Lerche, 1996). Among these factors, sedimentary facies and sedimentation rates are of primary importance in controlling fluid pressure development in a basin.

5) Differential compaction: The vertical stacking of sand-rich turbiditic palaeochannels leads to the formation of a large amplitude (i.e $10 \mathrm{~km}$ ) anticline due to differential compaction during burial (see Fig. 6).

In our study area, pockmarks are developping on the modern seafloor. Most of them are still active and present evidences of thermogenic fluids. This means that the above conditions are gathered: the fluids can migrate upward through the four levels of palaeochannels and reach the top of anticlines.

\section{Fluid storage under the hydrate layer}

Due to the ice-like nature of gas hydrates, hydrates-rich sediments may form a barrier to fluid flow, which inhibits sediment consolidation and can leads to the development of excess pore pressures at the BSR. Decomposition can also lead to a local reduction in shear strength at the BSR, so they could play an important role during slope failure (Booth et al., 1994). Gas migrating from underlying turbiditic palaeochannels may be trapped in anticline strata that are crosscut and capped at their updip ends by the base of the gas hydrate sediment (Dillon et al., 1980) leading to the occurrence of a BSR which mimic the stacked underlying palaeochannels. This is the case in our study area in which the BSR occurs at the top of the anticline structures, indicating that free gas is trapped beneath it.

\section{Migration through the Highly Faulted Interval}

Although the hydrate layer tends to temporarily inhibit fluid migration, a rapid increase of the overburden pressure can lead to the generation of excess pore fluid pressures (Bolton and Maltman, 1998), and fluids can escape from the free gas zone through the Highly-Faulted Interval, creating pockmarks on seafloor (Cole et al., 2000). A mechanism that would be very effective in mobilizing large volumes of fluids is the addition of another fluid, such as migrating hydrocarbons from deep source rocks into the sealed system (Jenkins, 1930; Gay et al., 2003; Brooke et al., 1995). In this case, pockmarks form in such fine sediments and not in sandy sediments as reported by Hovland in the North Sea (Hovland and Judd, 1988). A detailed study of the organization of faults and furrows shows that the pockmarks are consistently located at the intersection of three neighboring hexagons (Gay et al., 2004). The triple-junction of three neighboring hexagonal cells represents a preferential pathway for upward fluid migration from deeper levels. Consequently, the HFI represents an interval with a high drainage potential for pore fluids. In this context, the fluids 
migrating from deeper levels are preferentially driven through this interval along the pre-existing faults affecting all the HFI.

\section{Geochemical evidences of deep thermogenic fluids}

Geochemical analysis conducted on cores $\mathrm{Ca}$ and $\mathrm{Cd}$ (see Fig. 1 for location) within shallow sediments of pockmarks over the upper Miocene palaeochannel show strong evidences of a mix of biogenic methane and deep thermogenic fluids (methane and heavier hydrocarbons) (Gay et al., Submitted). The presence of thermogenic fluid within shallow sediments of cores $\mathrm{Ca}$ and $\mathrm{Cd}$ represents an evidence of thermogenic fluid migration from the reservoir (Söderberg and Flodén, 1992) up to the seafloor through the Highly-Faulted Interval.

\section{Model of fluids migrating from stacked turbidite palaeochannels}

We propose for the Lower Congo Basin a model of fluid migration through the sedimentary column which takes into account two kinds of sedimentation (Fig. 11): 1) a turbiditic sedimentation building channel-levee systems on the slope and 2) a hemipelagic sedimentation which tends to seal the first one.

Deep thermogenic fluids produced within Cretaceous source rocks are preferentially entrapped within the sandy bodies of turbiditic Oligocene-Miocene palaeochannels. They can migrate from a palaeochannel level to another one along faults which develop at the crest of the channel-levee system or along sand sill and dykes (Lonergan et al., 2000; Gay et al., 2003). The vertical stacking pattern of turbiditic palaeochannels allows the best pathway for fluids migration, as migration pathways (chimneys) are more concentrated when underlain by three to four stacked stacked palaeochannels. Once the fluids migrate to upper layer (Layer 1) of palaeochannels, they can can reach the seafloor via migration along closely-spaced normal faults of the Highly-Faulted Interval. They are temporarily inhibited below an interpreted 300 m-thick gas hydrate layer and accumulate under the hydrate stability zone to form a thick layer of free gas. In this case, the main factors controlling fluid entrapment is the presence of impermeable layers of hydrates leading to the generation of excess pore fluid pressure in the underlying free gas accumulation. The free gas can escape up to the seafloor along faults of the Highly-Faulted Interval forming pockmarks on the seafloor (Fig. 11). Although these pockmarks seem isolated they are clearly related to stacked Oligocene-Miocene turbiditic palaeochannels. 
Figure 11: Schematic block-diagram illustrating the likely relationship between stacked palaeochannels within the Oligocene-Miocene interval, the seismic chimneys under the BSR that concentrate fluids under the impermeable layer of hydrates, the seismic chimneys over the BSR and seafloor pockmarks. Ultimately, in this model fluids migrating through a large area are progressively concentrated to reach the seafloor at one point discharge site.

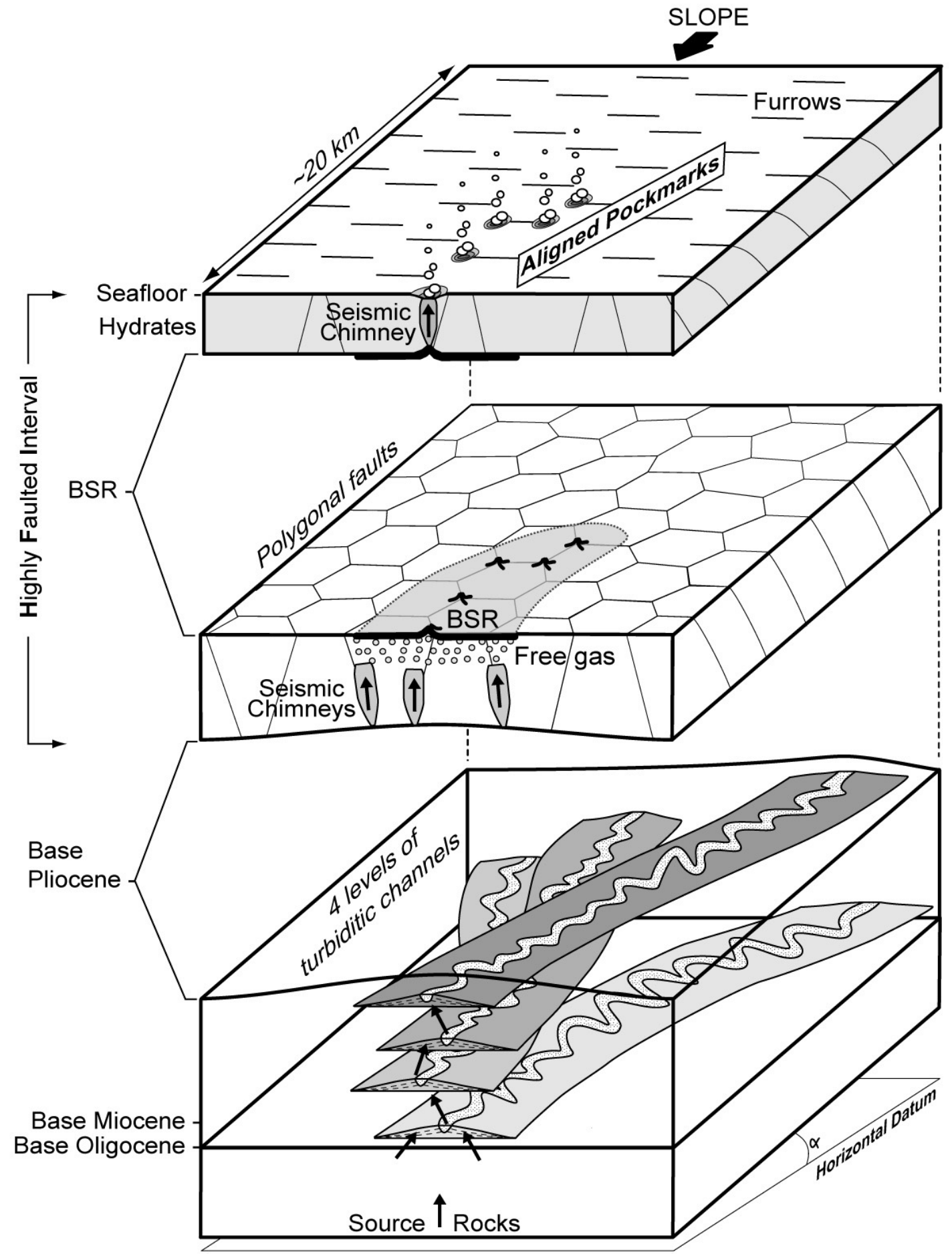


A.Gay et al - Pockmarks related to stacked turbiditic palaeochannels

\section{Conclusion}

This detailed study of pockmarks within the Lower Congo Basin shows that the fluid migration history is complex due to the inter-relation of tectonic features and sedimentary bodies. We show in this study that present-day seafloor pockmarks which seem isolated are most often related to:

1) Underlying gas-charged chimneys and these chimneys are located at the triple junction of three neighboring polygonal faults;

2) A BSR still visible on seismic section. The BSR shifts upward near the overlying chimney, indicating an active fluid flow into the gas hydrate stability zone;

3) A large number of seismic chimneys above the BSR. These chimneys allow to feed the free-gas zone under the hydrate layer;

4) Stacked Oligocene-Miocene turbiditic palaeochannels. Due to differential compaction during burial, this stacking leads to the formation of a large anticline, about $10 \mathrm{~km}$ wide, driving fluids at the crest.

The main restriction of this model is that the present day thermogenic fluid seepage on seafloor depends on an immediately underlying Mesozoic rift basin with an active petroleum system containing high-quality source rocks, which reaches the peak maturity at or about the same time as the mud-dominated Pliocene-Quaternary sediments were being deposited over the Oligo-Miocene turbiditic palaeochannels.

However, this system might follow the fault-valve behavior developed by Sibson (Sibson, 1992) and the fluid could escape periodically through the HighlyFaulted Interval (HFI). Such cycling could be recorded (mineralogically and/or biologically) within these pockmarks. However, further sampling and exploration are needed to address this issue.

\section{Acknowledgements}

The authors would like to express their gratitude to TOTAL for their financial support and data supplies and for supporting the publication of this work. We gratefully acknowledge Michel Seranne for the time and care he has taken in reading and reviewing this paper and for his insights tectonic point of view.

\section{Bibliography:}

Abrams, M. A., 1992. Geophysical and geochemical evidence for subsurface hydrocarbon leakage in the Bering Sea, Alaska. Marine and Petroleum Geology 9, 208-221.

Abrams, M. A., 1996. Distribution of subsurface hydrocarbon seepage in nearsurface marine sediments. In: Schumacher, D., M. A. Abrams (Eds.), Hydrocarbon Migration and its near-surface expression. AAPG Memoirs, vol. 66, pp. 1-14.

Anderson, J. E., J. Cartwright, S. J. Drysdall, N. Vivian, 2000. Controls on turbidite sand deposition during gravity-driven extension of a passive margin: examples 
from Miocene sediments in Block 4, Angola. Marine and Petroleum Geology 17, 1165-1203.

Babonneau, N., B. Savoye, M. Cremer, B. Klein, 2002. Morphology and architecture of the present canyon and channel system of the Zaire deep-sea fan. Marine and Petroleum Geology 19, 445-467.

Boe, R., L. Rise, D. Ottesen, 1998. Elongate depressions on the southern slope of the Nowegian trench (Skagerrak): morphology and evolution. Marine Geology 146, 191-203.

Bolton, A., A. Maltman, 1998. Fluid-flow pathways in actively deforming sediments: the role of pore fluid pressures and volume change. Marine and Petroleum Geology 15, 281-297.

Booth, J. S., W. J. Winters, W. P. Dillon, 1994. Circumstantial evidence of gas hydrate and slope failure associations on the United States Atlantic continental margin. Annals New York Academy of Sciences 715, 487-489.

Bouma, A. H., 1962. Sedimentology of some flysch deposits: a graphic approach to facies interpretation. Amsterdam, Elsevier, $168 \mathrm{p}$.

Brice, S. E., M. D. Cochran, G. Pardo, A. D. Edwards, 1982. Tectonics and Sedimentation of the South Atlantic Rift Sequence: Cabinda, Angola. In: Drake W. A. (Ed.), Studies in Continental Margin Geology. AAPG Memoirs, vol. 34, pp. 5-18.

Brooke, C. M., T. J. Trimble, T. A. Mackay, 1995. Mounded shallow gas sands from the Quaternary of the North Sea: analogues for the formation of sand mounds in deep water Tertiary sediments ?. In: Hartley, A.J., D. J. Prosser (Eds.), Characterization of Deep Marine Clastic Systems. Geological Society Special Publication, vol. 94, pp. 95-101.

Brown, A., 2000. Evaluation of possible gas microseepage mechanisms. AAPG Bulletin 84, 1775-1789.

Brown, A. R., 1996. Interpretation of three-dimensional seismic data. AAPG Memoirs, vol. 42, 424 p.

Bünz, S., J. Mienert, C. Berndt, 2003. Geological controls on the Storegga gashydrate system of the mid-Norwegian continental margin. Earth and Planetary Science Letters 209, 291-307.

Burollet, P. F., 1975. Tectonique en radeaux en Angola. Bulletin de la Société Géologique de France XXII, 503-504.

Burwood, R., 1999. Angola: source rock control for Lower Congo Coastal and Kwanza Basin petroleum systems. In: Cameron, N.R., R. H. Bate, V. S. Clure (Eds.), The Oil and Gas Habitats of the South Atlantic. Geological Society of London, vol. 153, pp. 181-184.

Cartwright, J., L. Lonergan, 1996. Volumetric contraction during the compaction of mudrocks: a mechanism for the development of regional-scale polygonal fault systems. Basin Research 8, 183-193.

Cartwright, J. A., 1994. Episodic basin-wide fluid expulsion from geopressured shale sequences in the North Sea basin. Geology 22, 447-450.

Cartwright, J. A. and D. N. Dewhurst, 1998. Layer-bound compaction faults in finegrained sediments. GSA Bulletin 110, 1242-1257.

Cartwright, J. A., L. Lonergan, 1997. Seismic expression of layer-bound fault systems of the Eromanga and North Sea Basins. Exploration Geophysics 28, 23-331.

Cole, D., S. A. Stewart, J. A. Cartwright, 2000. Giant irregular pockmark craters in the Palaeogene of the Outer Moray Firth Basin, UK North Sea. Marine and Petroleum Geology 17, 563-577.

Cooper, C. K., 1999. Ocean currents offshore Northern Angola. OTC paper 10749. 
Cunningham, R., R. M. Lindholm, 2000. Seismic evidence for widespread gas hydrate formation, offshore West Africa. In: M. R. Mello, B. J. Katz (Eds.), Petroleum systems of South Atlantic margins. AAPG Memoirs, vol. 73, pp. 93105.

De Batist, M., J. Klekx, P. Van Rensbergen, M. Vanneste, J. Poort, A. Golmshtok, A. Kremlev, O. Khlystov, P. Krinitsky, 2002. Active gas-hydrate destabilization and methane venting in Lake Baikal, Siberia ?. Terra Nova 14, 436-442.

Dillon, W., J. Grow, C. Paull, 1980. Unconventional gas hydrate seals may trap gas off southeast U.S. Oil and Gas Journal 78, 124-130.

Dimitrov, L., J. Woodside, 2003. Deep sea pockmarks environments in the eastern Mediterranean. Marine Geology 195, 263-276.

Droz, L., F. Rigaut, P. Cochonat, R. Tofani, 1996. Morphology and recent evolution of the Zaire turbidite system (Gulf of Guinea). GSA Bulletin 108, 253-269.

Duval, B., C. Cramez, M. P. A. Jackson, 1992. Raft tectonics in the Kwanza basin, Angola. Marine and Petroleum Geology 9, 389-404.

Eichhubl, P., H. G. Greene, T. Naehr, N. Maher, 2000. Structural control of fluid flow: offshore fluid seepage in the Santa Barbara Basin, California. Journal of Geochemical Exploration 69/70, 545-549.

Gay, A., M. Lopez, P. Cochonat, G. Sermondadaz, 2004. Polygonal faults-furrows system related to early stages of compaction - Upper Miocene to present sediments of the Lower Congo Basin. Basin Research 16, 101-116.

Gay, A., M. Lopez, P. Cochonat, G. Sermondadaz, Submitted. Evidences of early to late fluid migration from a Miocene turbiditic palaeochannel revealed by 3D seismic coupled to geochemical sampling within seafloor pockmarks, Lower Congo Basin. Marine and Petroleum Geology.

Gay, A., M. Lopez, P. Cochonat, N. Sultan, E. Cauquil, F. Brigaud, 2003. Sinuous pockmark belt as indicator of a shallow buried turbiditic channel on the lower slope of the Congo Basin, West African Margin. In: Van Rensbergen, P., R. R. Hillis, A. J. Maltman, C. K. Morley (Eds.), Subsurface Sediment Mobilization. Geological Society of London, Special Publications, vol. 216, pp. 173-189.

Giraudeau, J., B. A. Christensen, O. Hermelin, C. B. Lange, I. Motoyama, ODP Leg 175 Scientific Party, 1998. Biostratigraphic age models and sedimentation rates along the southwest African Margin. In: Wefer, G., W. H. Berger, C. Richter (Eds.), Proceedings of the Ocean Drilling Program, Initial Reports, vol. 175 , pp. 543-546.

Graue, K., 2000. Mud volcanoes in deepwater Nigeria. Marine and Petroleum Geology 17, 959-974.

Heggland, R., 1997. Detection of gas migration from a deep source by the use of exploration 3D seismic data. Marine Geology 13, 41-47.

Heggland, R., 1998. Gas seepage as an indicator of deeper prospective reservoirs. A study based on exploration 3D seismic data. Marine and Petroleum Geology 15, 1-9.

Hempel, P., V. Spiess, R. Schreiber, 1994. Expulsion of shallow gas in the Skagerrak- Evidence from subbottom profiling, seismic, hydroacoustical and geochemical data. Estuarine, Coastal and Shelf Science 38, 583-601.

Henriet, J. P., M. De Batist, M. Verschuren, 1991. Early fracturing of Palaeogene clays, southernmost North Sea: Relevance to mechanisms of primary hydrocarbon migration. In: Spencer, A.M. (Ed.), Generation, accumulation and production of Europe's hydrocarbons, European Association of Petroleum Geologists, Special Publication, vol. 1, pp. 217-227.

Hovland, M., J. Judd, 1988. Seabed pockmarks and seepages: Impact on Geology, Biology and Marine Environment. Graham and Trotman, London, 293 p. 
Hovland, M., J. V. Gardner, A. G. Judd, 2002. The significance of pockmarks to understanding fluid flow processes and geohazards. Geofluids 2, 127-136.

Hyndman, R. D., G. D. Spence, 1992. A seismic study of methane hydrate marine bottom simulating reflectors. JGR 97, 6683-6698.

Jansen, J. H., T. C. E. Van Weering, R. Gieles, J. Van Ipresen, 1984a. Middle and Late Quaternary oceanography and climatology of the ZAIRE-Congo fan and the adjacent eastern Angola Basin. Netherlands Journal of Sea Research 17, 201-249.

Jansen, J. H. F., P. Giresse, G. Moguedet, 1984b. Structural and sedimentary geology of the Congo and southern Gabon continental shelf; a seismic and acoustic reflection survey. Netherlands Journal of Sea Research 17, 364-384.

Jenkins, O. P., 1930. Sandstone dikes as conduits for oil migration through shales. AAPG bulletin 14, 411-421.

Jennette, D. C., K. Fouad, T. Wawrzyniec, D. Dunlap, R. Munoz, J. Meneses-Rocha, 2003. Slope and basin-floor reservoirs from the Miocene and Pliocene of the Veracruz Basin, southeastern Mexico. Marine and Petroleum Geology 20, 587-600.

Johnson, J. E., C. Goldfinger, E. Suess, 2003. Geophysical constraints on the surface distribution of authigenic carbonates across the Hydrate Ridge region, Cascadia Margin. Marine Geology 202, 79-120.

Josenhans, H. W., L. H. King, G. B. Fader, 1978. A side-scan sonar mosaic of pockmarks on the Scotian shelf. Canadian Journal of Earth Sciences 15, 831840.

Karner, G. D., N. W. Driscoll, J. P. McGinnis, W. D. Brumbaugh, N. R. Cameron, 1997. Tectonic significance of syn-rift sediment packages across the GabonCabinda continental margin. Marine and Petroleum Geology 14, 973-1000.

Kelley, J. T., S. M. Dickson, D. F. Belknap, W. A. Barnhardt, M. Henderson, 1994. Giant sea-bed pockmarks: evidence for gas escape from Belfast Bay, Maine. Geology 22, 59-62.

Klitgord, K. D., and J. A. Grow, 1980. Jurassic seismic stratigraphy and basement structure of the western Atlantic magnetic quiet zone. AAPG bulletin 64, 1658-1680.

Kvenvolden, K. A., L. A. Barnard, 1983. Gas hydrates of the blake outer ridge, site 533. Deep Sea Drilling Project leg 76. In: Sheridan, R.E., F. Grastein (Eds.), Initial Reports Deep Sea Drilling Project, vol. 76, pp. 353-365.

Lastras, G., M. Canals, R. Urgeles, J.-E. Hughes-Clarke, J. Acosta, 2004. Shallow slides and pockmark swarms in the Eivissia Channel, western Mediterranean Sea. Sedimentology 51, 1-14.

Liro, L. M., R. Cohen, 1995. Salt deformation history and postsalt structural trends, offshore southern Gabon, west Africa. In: Jackson, M.P.A., D. G. Roberts, S. Snelson (Eds.), Salt tectonics: a global perspective, AAPG Memoirs, vol. 65, pp. 323-331.

Loncke, L., J. Mascle, Fanil Science Party, 2004. Mud volcanoes, gas chimneys, pockmarks and mounds in the Nile deep-sea fan (Eastern Mediterranean): geophysical evidences. Marine and Petroleum Geology 21, 669-689.

Lonergan, L., J. Cartwright, R. Jolly, 1998a. The geometry of polygonal fault systems in Tertiary mudrocks of the North Sea. Journal of Structural Geology 20, 529548.

Lonergan, L., J. Cartwright, R. Laver, J. Staffurth, 1998b. Polygonal faulting in the Tertiary of the Central North Sea - Implications for reservoir geology. In: Coward, M.P., T. S. Daltaban, H. Johnson (Eds.), Structural geology in 
reservoir characterization. Geological Society of London, Special Publication, vol. 127, pp. 191-207.

Lonergan, L., N. Lee, H. D. Johnson, J. Cartwright, R. Jolly, 2000. Remobilization and Injection in Deepwater Depositional Systems: Implications for Reservoir Architecture and Prediction. In: Weimer, P, et al. (Eds.), Deepwater reservoirs of the world, GCSSEPM 20th Annual Research Conference, 515-532.

Lowe, D. R., 1982. Sediment gravity flows: II depositional models with special reference to the deposits of high energy turbidity currents. Journal of Sedimentary Petrology 50, 279-297.

Lundin, E. R., 1992. Thin-skinned extensional tectonics on a salt detachment, northern Kwanza basin, Angola. Marine and Petroleum Geology 9, 405-411.

MacKay, M. E., R. D. Jarrard, G. K. Westbrook, R. D. Hyndman, Shipboard Scientific Party of Ocean Drilling Program Leg 146, 1994. Origin of bottom-simulating reflectors: Geophysical evidence from the Cascadia accretionary prism. Geology 22, 459-462.

Marton, L. G., G. C. Tari, C. T. Lehmann, 2000. Evolution of the Angola passive Margin, West Africa, with Emphasis on Post-Salt Structural Styles. In: Moriak, W., M. Talwani (Eds.), Atlantic Rifts and Continental Margins, American Geophysical Union, Washington DC, 129-149.

Oldham, A. C., N. M. Gibbins, 1995. Lake Hope 3D: A case study. Exploration Geophysics 26, 383-394.

Orange, D. L., H. G. Greene, D. Reed, J. B. Martin, C. M. McHugh, W. B. F. Ryan, N. Maher, D. Stakes, J. Barry, 1999. Widespread fluid expulsion on a translational continental margin: Mud volcanoes, fault zones, headless canyons, and organic-rich substrate in Monterey Bay, California. GSA Bulletin 111, 992-1009.

Paull, C., W. Ussler III, N. Maher, H. G. Greene, G. Rehder, T. Lorenson, H. Lee, 2002. Pockmarks off Big Sur, California. Marine Geology 181, 323-335.

Poag, C. W., A. B. Watts, et al., 1987. Initial reports of the Deep Sea Drilling Project, vol. 95, $817 \mathrm{p}$.

Pufahl, P. K., G. Wefer, 2001. Lithostratigraphic summary for LEG 175: AngolaBenguela upwelling system - Chapter 15. In: Wefer, G., W. H. Berger, C. Richter (Eds.), Proceedings of the Ocean Drilling Program, Scientific Results, vol. 175, pp. 1-17.

Richard, M., M. Bowman, 1998. Submarine fans and related depositional systems II: variability in reservoir architecture and wireline log character. Marine and Petroleum Geology 15, 821-839.

Rouby, D., S. Raillard, F. Guillocheau, R. Bouroullec, T. Nalpas, 2002. Kinematics of a growth fault/raft system on the West African margin using 3-D restoration. Journal of Structural Geology 24, 783-796.

Savoye, B., P. Cochonat, et al., 2000. Structure et évolution récente de l'éventail turbiditique du Zaire: premier résultats scientifiques des missions d'exploration Zaiango 1 et 2 (Marge Congo-Angola). Comptes-Rendus de l'Académie des Sciences de la Terre et des Planètes 331, 211-220.

Schmuck, E. A., C. K. Paull, 1993. Evidence for gas accumulation associated with diapirism and gas hydrates at the head of the Cape Fear Slide. Geo-Marine Letters 13, 145-152.

Seranne, M., 1999. Early Oligocene stratigraphic turnover on the west Africa continental margin: a signature of the Tertiary greenhouse-to-icehouse transition ?. Terra Nova 11, 135-140. 
Seranne, M., M. Seguret, M. Fauchier, 1992. Seismic super-units and post-rift evolution of the continental passive margin of southern Gabon. Bulletin de la Société Géologique de France 163, 135-146.

Shaw, J., R. C. Courtney, J. R. Currie, 1997. Marine geology of St. George's Bay, Newfoundland, as interpreted from multibeam bathymetry and back-scatter data. Geo-Marine Letters 17, 188-194.

Shipley, T. H., M. H. Houston, R. T. Buffler, F. J. Shaub, K. J. McMillen, J. W. Ladd, J. L. Worzel, 1979. Seismic evidence for widespread possible occurence of gas-hydrate horizons or continental slopes and rises. AAPG Bulletin 63, 2204-2213.

Sibson, R. H., 1992. Implications of fault-valve behaviour for rupture nucleation and recurrence. Tectonophysics 211, 283-293.

Söderberg, P., T. Flodén, 1992. Gas seepages, gas eruptions and degassing structures in the seafloor along the Strömma tectonic lineament in the crystalline Stockholm Archipelago, east Sweden. Continental Shelf Research 12, 1157-1171.

Soter, S., 1999. Macroscopic seismic anomalies and submarine pockmarks in the Corinth-Patras rift, Greece. Tectonophysics 308, 275-290.

Stewart, S. A., 1999. Seismic interpretation of circular geological structures: Petroleum Geoscience 5, 273-285.

Taylor, M. H., W. P. Dillon, I. A. Pecher, 2000. Trapping and migration of methane associated with the gas hydrate stability zone at the Blake Ridge Diapir: new insights from seismic data. Marine Geology 164, 79-89.

Tingdahl, K. M., A. H. Bril, P. F. de Groot, 2001. Improving seismic chimney detection using directional attributes. Journal of Petroleum Science and Engineering 29, 205-211.

Tokunaga, T., 2000. The role of turbidites on compaction and dewatering of underthrust sdiments at the toe of the northern Barbados accretionary prism: new evidence from logging While Drilling, ODP Leg 171A. Earth and Planetary Science Letters 178, 385-395.

Uchupi, E., 1992. Angola Basin: Geohistory and Construction of the Continental Rise. In: Poag, C.W., P. A. De Graciansky (Eds.), Geologic Evolution of Atlantic Continental Rifts, Nostrand Reinhold, New York, pp. 77-99.

Uenzelmann-Neben, G., 1998. Neogene sedimentation history of the Congo Fan. Marine and Petroleum Geology 15, 635-650.

Ussler III, W., C. K. Paull, J. Boucher, G. E. Friederich, D. J. Thomas, 2003. Submarine pockmarks: a case study from Belfast Bay, Maine. Marine Geology 202, 175-192.

Vogt, P. R., J. Gerdner, K. Crane, E. Sundvor, F. Bowles, G. Cherkashev, 1999. Ground-truthing 11- to $12-\mathrm{kHz}$ side-scan sonar imagery in the NorwegianGreenland Sea. Part I: Pockmarks on the Vestnesa Ridge and Storegga slide margin. Geo-Marine Letters 19, 97-110.

Wefer, G., W. H. Berger, C. Richter, Scientific Party, 1998. Facies patterns and authigenic minerals of upwelling deposits off Southwest Africa, Proceedings of the Ocean Drilling Program, Initial Reports, vol.175, pp. 487-504.

Whiticar, M. J., F. Werner, 1981. Pockmarks : Submarine vents of natural gas or freshwater seeps ?. Geo-Marine Letters 1, 193-199.

Yu, Z., I. Lerche, 1996. Modelling abnormal pressure development in sandstone/shale basins. Marine and Petroleum Geology 13, 179-193.

Zühlsdorff, L., V. Spieß, 2004. Three-dimensional seismic characterization of a venting site reveals compelling indications of natural hydraulic fracturing. Geology 32, 101-104. 